\title{
BIM2PHPP: A New BIM-Based Tool for Passivhaus Design With PHPP
}

\author{
Omar Sadeq Hamed ${ }^{1,2}$, Tsung-Hsien Wang ${ }^{1}$ \\ ${ }^{1}$ University of Sheffield, Sheffield, United Kingdom \\ ${ }^{2}$ Al-Ahliyya Amman University, Amman, Jordan \\ oshamed1@sheffield.ac.uk
}

\begin{abstract}
The Passivhaus buildings can significantly reduce energy consumption when compared to conventional practice for new buildings. Achieving the Passivhaus certificate requires complying to a set of rules and meeting the energy limit criteria. Assessing building energy performance is conducted using the Passive House Planning Package (PHPP). Users can input all required information manually, or they can prepare information needed using SketchUp with DesignPH plugin. In this paper, we developed a new computational workflow for data exchange between Building Information Modelling (BIM) and PHPP. This research aims to develop a BIMbased tool that facilitates prescribed evaluation by PHPP. The proposed tool can collect, process and export BIM model data to the PHPP through Dynamo-a visual scripting platform for Revit. We demonstrated the automation of Passivhaus evaluation by facilitating both geometrical and non-geometrical information interoperation between BIM models and the PHPP tool.
\end{abstract}

\section{Introduction}

Within the rising awareness of the impact of the building industry on the environment, the building sector is moving towards sustainability (Junnila and Horvath, 2003). This led to introducing different sustainable rating systems, standards, and certificates (Vierra, 2016). Passivhaus is one of the low energy design standards that aim to reduce buildings carbon footprint by complying to its low energy requirements (Passipedia, 2018). To achieve the Passivhaus certificate, the building should be assessed using the Passive House Planning Package (PHPP). Building Information Modelling has shown notable technical developments over conventional CAD tools. Some of the critical features BIM provides range from time and cost savings, technical superiority, and the information captured about buildings through the design process (Harris and McCaffer, 2013). In addition, the compatibility between BIM tools and visual programming platforms, such as Dynamo, offers a better opportunity to enhance the building design process and data management (Autodesk, 2016). While BIM supports sustainable design (Biswas, Wang and Krishnamurti, 2013), interoperability between BIM and PHPP is limited (Cemesova, Hopfe and McLeod, 2015). This paper aims to develop a BIM-based approach using Dynamo to automate project information exchange between BIM and
PHPP. The proposed approach facilitates the sustainable design process, by reducing time and effort through the iterative design process for low energy design standards - the Passivhaus.

\section{Literature review}

\section{Sustainable buildings}

Within the growing awareness about sustainability, the building industry was one of the major sectors that adopted sustainability. Taking in consideration the significant impact on the consumed resources and the lasting impact of the construction sector (Junnila and Horvath, 2003; Ebert, Eßig and Hauser, 2011), various green building certificates, standards, and rating systems have been developed to reduce buildings impact on the natural environment (Vierra, 2016). For this research, the Passivhaus certificate was chosen as a low energy design standard to conduct the study.

\section{Passivhaus}

The Passive House concept was developed by collaborative work between Bo Adamson of Lund University and Dr Wolfgang Feist in Sweden (Proietti et al., 2013). Compared to the common practice in the UK, Passivhaus buildings are capable of achieving up to $75 \%$ reduction in space heating requirements (Passivhaus Trust, 2018).

To achieve the Passivhaus certificate for new buildings, an overall low energy standard should be met (Passivhaus Trust, 2018). However, it is mandatory that the primary energy, space heating, domestic hot water, lighting, fans and pumps, and all other appliance consumption demand levels are met in all cases.

\section{The Passive House Planning Package (PHPP)}

The Passive House Planning Package (PHPP) was first introduced in a spreadsheet format in 1998, and since then it has been under continuous development and validation based on new research findings and measured values (Passipedia, 2018). The mandatory step is to verify the designed building's energy balance by using the PHPP tool. The Passivhaus certificate can then be achieved once the defined low energy performance standards were met (Passivhaus Trust, 2018).

In the current practice, building geometrical information and material attributes can be transferred into the PHPP worksheets by one of two methods: (1) manual data entry, which is time-consuming, and may lead to errors related 
to duplication or missing data, or even inaccurate data entry; or (2) by using a plug-in designed by the Passive House Institute (PHI) called DesignPH (The Passive House Institute, 2018). This plug-in is compatible only with the SketchUp software and capable of transferring geometrical model information into "U-values", "Areas", "Windows", "Shading" and "Components" sheets in a PHPP file (The Passive House Institute, 2018). To use the DesignPH, the user has to create an energy model using SketchUp environment and manually assign thermal and material properties for all model elements (The Passive House Institute, 2018). These properties can be defined using the DesignPH library. After an energy model is created, it can be exported as a "PPP" file to the PHPP (Feist et al., 2013; The Passive House Institute, 2018).

\section{Building Information Modelling (BIM)}

Building Information Modelling (BIM) has been described as " the technology of generating and managing a parametric model of a building" (Harris and McCaffer, 2013). Using BIM provides various benefits, ranging from time to cost savings, technical superiority, capabilities of interoperability, early capture of building information, building lifecycle, and also reducing errors and design collision risks (Harris and McCaffer, 2013; Ghaffarianhoseini et al., 2017). It has shown a major technical advancement on traditional CAD tools by offering more interoperability and intelligent capabilities (Miettinen and Paavola, 2014).

Comprehensive information about the building has been enabled to be captured by BIM tools alongside the design process. This information ranges from the individual components of the building and locations to the relationship between these elements (Ghaffarianhoseini et al., 2017). Also, BIM consolidates various building information such as geometrical information and spatial organization, daylight studies, location information, building materials and their physical and thermal attributes (such as U-value, fire rating classification), costs analysis and quantities schedules. In turn, these features allow designers to keep tracking the relationships between building elements and their constructionmaintenance information (Ghaffarianhoseini et al., 2017).

BIM provides a great opportunity to evaluate sustainability throughout the iterative design process using a fully-integrated information model. For instance, a wealth of information carried by a building information model can produce the required documents for earning LEED credits or other rating systems (Biswas, Wang and Krishnamurti, 2008, 2013; Azhar et al., 2011). This project shares the same interest in reusing the information provided in a BIM model to enable seamless integration and evaluation for the Passivhaus design.

\section{Dynamo for performance analysis}

Dynamo was introduced as an open source Visual Programming tool to enhance the building design process and information exchange workflow in both Building Information Modelling (BIM) and computational design aspects (Autodesk, 2016). It aids designers to develop an algorithmic approach by its friendly Graphical User
Interface (GUI) (Krygiel and Vandezande, 2014). By providing a node- based environment, it reduces the time and effort needed to learn programming (Reinhardt and Matthews, 2017). This allows designers to create custom algorithms by allying pre-designed nodes together (Seghier et al., 2017).

Interoperability among BIM and performance analysis tools is considered as one of the major challenges in the architecture, engineering and construction industry (AEC) (Bahar et al., 2013). Industrial Foundation Classes (IFC), and green building extensible markup language ( $g b X M L)$ are considered to be the most developed and widespread data schemas used to exchange information between BIM applications (B. Dong et al., 2007; Bahar et al., 2013; Motawa and Carter, 2013; Biswas, 2015; Farzaneh, Monfet and Forgues, 2019; Kamel and Memari, 2019). Several studies have adopted IFC and gbXML formats for project information exchange for BIM-based performance analysis. Ilhan and Yaman (2016) introduced an IFC-based framework to integrate BIM platform that facilitates generation of green building certificate documents to bridge the gap between green building assessments and BIM to simplify design decisions in early project phases. Azhar developed a framework to link LEED credits with the related BIMbased sustainability analysis using a gbXML approach to streamline the LEED certification process and save substantial time and resources (Azhar et al., 2011).

In the last five years, visual programming tools have been adopted in several studies to integrate BIM with building performance analysis (Seghier et al., 2017). Bergonzoni et al. (2016) introduced an automated approach to automate the calculation process for LEED IEQ category prerequisites and credits, by using Dynamo to integrate the BIM authoring tool (Autodesk Revit) with electronic spreadsheets. Reinhardt and Matthews (2017) introduced an automated checking system for building regulations by developing Dynamo scripts that facilitate information exchange between Revit and excel templates. Sanhudo and Martins (2018) developed an approach of connecting BIM to automate the rainfall runoff volume calculation for LEED Stormwater Runoff Management calculations. Seghier et al. (2017) presented a BIM- VPL (Visual Programming Language) based tool for building envelope design and assessment support, focusing on the energy efficiency requirements in GreenRE and Green Mark rating systems in a framework that integrates both the BIM-VPL based functions and energy efficiency requirements (Seghier et al., 2017).

\section{Automating Passivhaus Evaluation using BIM}

In common practice, certified Passivhaus buildings are tested and certified using the PHPP tool. Users can manually input all required information, e.g., building geometry information and material properties directly into the spreadsheets. Alternatively, users can create an energy model through a conventional 3D CAD environment with an add-on tool, such as the designPH tool-a plugin that supports the need to associate raw 
geometric data with required physical attributes, such as surfaces, components' thermal properties, etc. However, as PHPP is an excel spreadsheet, data interoperability between BIM tools and PHPP is currently limited (Cemesova, Hopfe and McLeod, 2015).

This study aims to introduce a new BIM-based approach to automate the sustainability evaluation process of the Passivhaus. The presented tool was proposed to enable information interoperation directly from a BIM model to the PHPP sheets. The main objective is to reduce significant time and efforts for Passive house design through the automation of data exchange. For the demonstration, the authors deployed the tool in Dynamo for Autodesk Revit and illustrated how building elements and associated information, such as Wall, U-values and their orientations are calculated and extracted to the PHPP sheets for Passivhaus design evaluation.

\section{Tool development}

According to Feist et al. (2013), the thermal envelope of a building is calculated based on the external dimensions of every thermal element. Therefore, all the external areas considered as thermal elements must be defined and extracted. For example, all windows, roofs, and walls that form the thermal envelope, their material, orientation, and other physical attributes are required information that needs to be extracted and defined in the PHPP spreadsheets.

While BIM model consolidates various building information such as building components and their areas, dimensions, thermal attributes, some information related to the building components requires more effort to be extracted from BIM models. For example, components orientation from the True North cannot be found directly in Revit elements. To overcome this issue, a custom node was developed for the BIM2PHPP toolkit to automatically measure the orientation of the exterior wall and ceiling surface(s).

PHPP spreadsheets also require extra information that can only be used to define the role of each component in the thermal envelope. For example, element Group Number is one of the required inputs for each component to define whether it is an ambient or a ground-exterior wall, roof/ceiling, and floor slab. To identify the Group Number issue, a custom node was developed to define new instance parameter for wall components (Exterior
Wall) to filter exterior walls. Another instance parameter (Is Ground Wall) was also defined to categorise the wall group. Table 1 shows a summary of the PHPP required information and the development of this information in the BIM2PHPP toolkit.

Table 1 PHPP requirements, availability in Revit, and the development of BIM2PHPP toolkit.

\begin{tabular}{|c|c|c|c|}
\hline Component & $\begin{array}{l}\text { PHPP } \\
\text { Requirement }\end{array}$ & $\begin{array}{l}\text { Availability } \\
\text { in Revit }\end{array}$ & $\begin{array}{l}\text { BIM2PHPP } \\
\text { toolkit }\end{array}$ \\
\hline \multirow{8}{*}{$\begin{array}{l}\text { Walls \& } \\
\text { Roofs }\end{array}$} & area & yes & yes \\
\hline & Group number & - & $\begin{array}{l}\text { yes (user } \\
\text { input) }\end{array}$ \\
\hline & $\begin{array}{l}\text { Thermal } \\
\text { properties }\end{array}$ & yes & yes \\
\hline & $\begin{array}{l}\text { Deviation from } \\
\text { North }\end{array}$ & - & yes \\
\hline & $\begin{array}{l}\text { The angle of } \\
\text { Inclination from } \\
\text { the horizontal }\end{array}$ & - & yes \\
\hline & $\begin{array}{l}\text { Reduction } \\
\text { shading factor }\end{array}$ & - & $\begin{array}{l}\text { yes } \\
\text { (defaulted) }\end{array}$ \\
\hline & $\begin{array}{l}\text { Exterior } \\
\text { absorptivity }\end{array}$ & yes & yes \\
\hline & $\begin{array}{l}\text { Exterior } \\
\text { emissivity }\end{array}$ & - & $\begin{array}{l}\text { yes } \\
\text { (defaulted) }\end{array}$ \\
\hline \multirow{6}{*}{ Windows } & dimensions & yes & yes \\
\hline & $\begin{array}{l}\text { Hosting } \\
\text { component }\end{array}$ & - & yes \\
\hline & $\begin{array}{l}\text { Component } \\
\text { information } \\
\text { (glazing and } \\
\text { frame types) }\end{array}$ & yes & yes \\
\hline & $\begin{array}{l}\text { Thermal } \\
\text { properties (U- } \\
\text { value, G-value) }\end{array}$ & yes & yes \\
\hline & orientation & - & yes \\
\hline & $\begin{array}{l}\text { Shading } \\
\text { calculations }\end{array}$ & - & - \\
\hline \multirow{2}{*}{$\begin{array}{l}\text { Window } \\
\text { frame }\end{array}$} & $\begin{array}{l}\text { Glazing edge } \\
\text { thermal bridge }\end{array}$ & - & $\begin{array}{l}\text { yes } \\
\text { (defaulted) }\end{array}$ \\
\hline & $\begin{array}{l}\text { Installation } \\
\text { thermal bridge }\end{array}$ & - & $\begin{array}{l}\text { yes } \\
\text { (defaulted) }\end{array}$ \\
\hline
\end{tabular}

\section{BIM2PHPP computational workflow}

The BIM2PHPP toolkit workflow includes three main phases: (1) Information Modelling and Preparation; (2) Data Processing and Calculation; (3) Data mapping and

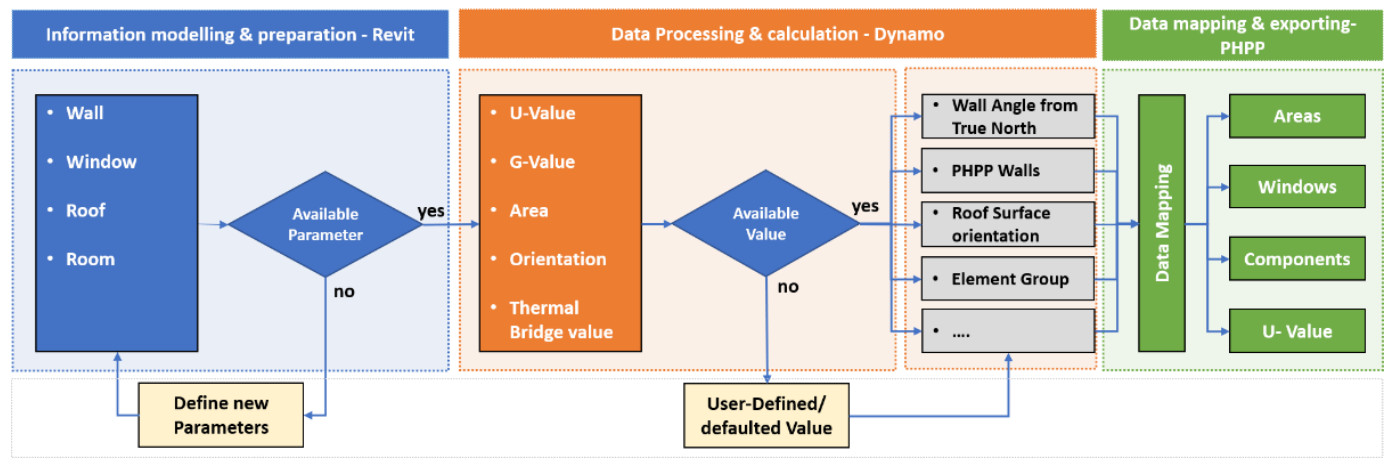

Figure 1 BIM2PHPP workflow 
Exporting, as shown in Figure 1. To initiate the evaluation process, the user is required to check the availability of all the required parameters of the proposed design model using a customized node. If a parameter is missing, a new parameter will be defined. The values of the new parameters would be filled either by the user or defaulted in an automated process by the tool. The next step is to process acquired model information and performs the necessary calculation for PHPP. Finally, model information can be mapped and exported to the PHPP tool.

\section{Tool demonstration}

The proposed workflow requires interaction between three tools: (1) Autodesk Revit: to create the proposed model, and define the missing parameters values; (2) Dynamo: firstly to define the missing parameters, secondly, to collect all model information, and finally, to export model information and read the PHPP analysis results; (3) PHPP spreadsheets, in which the analysis can be done. For example, the total Treated Floor Area (TFA), which represents the useful area or living space, is one of the required information in the Areas sheet in PHPP. As Revit components do not contain such a parameter, a new instance parameter will be defined for Room components.

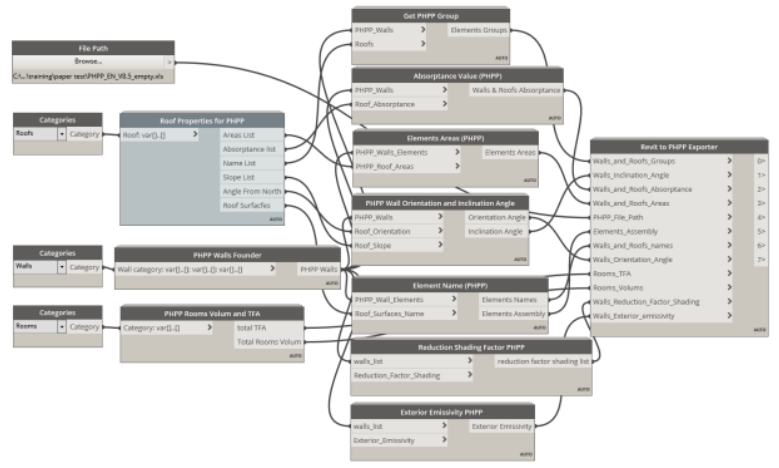

Figure 2 BIM2PHPP script for Areas sheet

However, the new parameter (TFA Percentage) requires user input to calculate the (Room TFA) based on the use of each space. According to Feist et al. (2013), the areas are weighted by $(100 \%$ or $60 \%)$. Once all rooms TFA values were given, the Dynamo script will automatically calculate all the project TFA. After that, data mapping is then processed to export the TFA of the Project to the Areas sheet inside the PHPP tool. Figure 2 shows part of the tool to process, map, and export information into the Areas sheet.

Figure 3 shows the interaction between the tools and their roles. For further demonstration, the following steps describe the process of the overall workflow.

1- Create the model using Revit.

2- Run a custom node in BIM2PHPP tool to define the missing parameters.

3- Some of the defined parameters need user inputs to fulfil the missing data required in PHPP spreadsheets.
4- After collecting all the required information, the data mapping process is then completed within the complete tool workflow.

5- Finally, the model performance can be analysed by exporting the collected information to the PHPP tool.

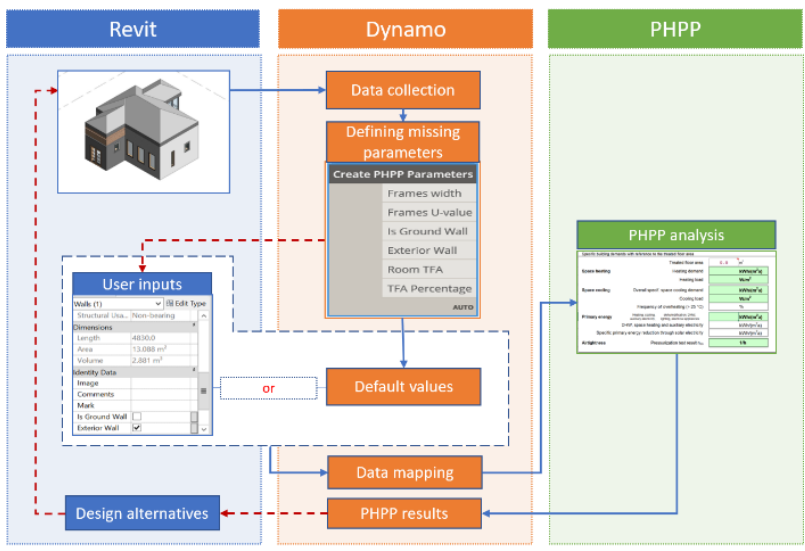

Figure 3 tool demonstration

The tool also has the capability to read the analysis results from PHPP spreadsheets, which allows the user to have instant feedback on the design performance. However, if the PHPP requirements have not been fulfilled, the user can apply different design solutions to fulfil the requirements.

\section{Discussions and conclusions}

\section{Discussions}

The developed tool aims to support the automation of sustainable design evaluation using PHPP. The tool features three different levels of automation: (1) Fullyautomated process, in which the tool can automatically collect, calculate, map and extract the available data from the model to the PHPP tool, such as component orientation detection; (2) Semi-automated process, which requires user input/ defaulted-values for the missing parameters, such as TFA percentage. Once the missing values are filled, the process can be automated; (3) Manual process, which can only be done manually, such as shading calculations.

BIM2PHPP tool offers an automated process for data extraction and export to "U-values", "Areas", "Components" and "Windows" sheets by using existing BIM model information. However, missing information can be fulfilled either as a defaulted value in an automated process by the tool or by user inputs. On the other hand, using DesignPH plugin as a graphical interface for the PHPP tool requires manual inputs for all building assembly information and material attributes. This information needs to be assigned to an energy model created by the user in the SketchUp environment. Table 2 highlights the key differences between DesignPH and BIM2PHPP.

\section{Limitations and future work}

The focus of this research was to facilitate sustainable design practice by automating the evaluation process for Passivhaus design. The tool has shown the capability of 
reducing time and effort by semi-automating data extraction, mapping, and export from BIM models to the PHPP spreadsheets. The main challenge remains the availability of the required data in BIM models. As BIM2PHPP tool extracts and processes the existing building information, some of these data would not be available in the BIM model. However, for a fully automated process, the user had to define some missing parameters. These parameters can either be defaulted or requiring direct inputs by the user to complete the process. Future research could be conducted to facilitate a multidisciplinary collaboration to cover more data exchange, which would improve the efficiency of the BIM2PHPP tool.

Table 2 the main features of DesignPH and BIM2PHPP toolkit

\begin{tabular}{|c|c|c|c|}
\hline \multicolumn{2}{|c|}{ Comparison area } & $\begin{array}{l}\text { DesignPH } \\
\text { plugin }\end{array}$ & $\begin{array}{l}\text { BIM2PHPP } \\
\text { toolkit }\end{array}$ \\
\hline \multicolumn{2}{|c|}{ Base software } & SketchUp & $\begin{array}{l}\text { Autodesk } \\
\text { Revit/ } \\
\text { Dynamo }\end{array}$ \\
\hline \multicolumn{2}{|c|}{ Energy model } & $\begin{array}{l}\text { Requires an } \\
\text { energy model } \\
\text { and assigning } \\
\text { thermal } \\
\text { properties, } \\
\text { TFA, group } \\
\text { areas, window } \\
\text { components }\end{array}$ & $\begin{array}{l}\text { Not required/ } \\
\text { data } \\
\text { extraction } \\
\text { from the BIM } \\
\text { model }\end{array}$ \\
\hline \multirow{4}{*}{$\begin{array}{l}\text { Data } \\
\text { availability }\end{array}$} & Areas & User input & Yes \\
\hline & Orientation & Yes & Yes \\
\hline & $\begin{array}{l}\text { Elements } \\
\text { Thermal } \\
\text { properties }\end{array}$ & User input & $\begin{array}{l}\text { Yes/ default } \\
\text { values/ user } \\
\text { input }\end{array}$ \\
\hline & $\begin{array}{l}\text { Materials } \\
\text { properties }\end{array}$ & User input & Yes \\
\hline \multicolumn{2}{|l|}{ Data input } & $\begin{array}{l}\text { Manual input } \\
\text { through } \\
\text { SketchUp 3D } \\
\text { environment. } \\
\text { This requires } \\
\text { user input or the } \\
\text { use of default } \\
\text { information in } \\
\text { the library }\end{array}$ & $\begin{array}{l}\text { For some } \\
\text { missing } \\
\text { parameters, } \\
\text { user input is } \\
\text { required }\end{array}$ \\
\hline \multicolumn{2}{|c|}{ Shading calculations } & Yes & \\
\hline \multicolumn{2}{|c|}{ In-software analysis } & Yes & $\begin{array}{l}\text { No, but } \\
\text { Results can be } \\
\text { read from } \\
\text { PHPP }\end{array}$ \\
\hline \multicolumn{2}{|c|}{ Fully-automated process } & $\begin{array}{l}\text { Semi-automated } \\
\text { process }\end{array}$ & $\square \begin{array}{l}\text { Manual } \\
\text { process }\end{array}$ \\
\hline
\end{tabular}

\section{Conclusions}

In this paper, we introduced a new BIM-VPL based approach that bridges the gap of information exchange between BIM and PHPP tool. The proposed approach streamlines the design assessment for Passivhaus using BIM authoring tool (Autodesk Revit) by automating project information exchange into PHPP spreadsheets. This will help to reduce a significant effort needed for manual data entry, reduce time and eliminate errors through the automated data input process, and will help the designers to focus on the design process. We demonstrated how the BIM2PHPP tool could be applied efficiently and effectively to retrieve all geometric information and material attributes needed for the Passivhaus design assessment using PHPP. We acknowledge that not all required information would always be available in a BIM model. This paper has discussed how these gaps were first analysed and tackled to enable the evaluation. As a result, a BIM tool was developed and deployed in Dynamo for Autodesk Revit to automatically associate and prepare default and/or userdefined values for PHPP. This streamlined process affords users a great capability to investigate various design scenarios efficiently and reduce a great effort and time on the need for design validation during the iterative design process.

\section{References}

Autodesk (2016) Discover Dynamo. Available at: http://dynamobim.org/ explore/ (Accessed: 16 December 2018).

Azhar, S. et al. (2011) 'Building information modeling for sustainable design and LEED®rating analysis', Automation in Construction. Elsevier B.V., 20(2), pp. 217-224. doi: 10.1016/j.autcon.2010.09.019.

B. Dong et al. (2007) 'A comparative study of the IFC and gbXML informational infrastructures for data exchange in computational design support environments', Proceedings Building Simulation 2007, 1, pp. 1530-1537. Available at: http://www.ibpsa.org/proceedings/BS2007/p363_fina 1.pdf\%0Ahttp://www.mendeley.com/research/acomparative-study-of-the-ifc-and-gbxmlinformational-infrastructures-for-data-exchange-incomputational-design-support-environments/.

Bahar, Y. et al. (2013) 'A Thermal Simulation Tool for Building and Its Interoperability through the Building Information Modeling (BIM) Platform', Buildings, 3(2), pp. 380-398. doi: 10.3390/buildings3020380.

Biswas, T. (2015) 'Towards a Framework for Supporting Sustainable Building Design: A case study of two credits over evolving rating standards'.

Biswas, T., Wang, T.-H. and Krishnamurti, R. (2008) 'Integrating sustainable building rating systems with building information models', 13th International Conference on Computer Aided Architectural Design Research in Asia, pp. 193-200. Available at: http://cumincad.scix.net/data/works/att/caadria2008_ 24_session3a_193.content.pdf.

Biswas, T., Wang, T.-H. and Krishnamurti, R. (2013) 'From Design To Pre-Certification Using Building Information Modeling', Journal of Green Building, 8(1), pp. 151-176. doi: 10.3992/jgb.8.1.151.

Cemesova, A., Hopfe, C. J. and McLeod, R. S. (2015) 'PassivBIM: Enhancing interoperability between BIM and low energy design software', Automation in Construction. Elsevier B.V., 57, pp. 17-32. doi: 10.1016/j.autcon.2015.04.014.

Ebert, T., Eßig, N. and Hauser, G. (2011) Green Building Certification Systems: Assessing sustainability - 
International system comparison - Economic impact of certifications. 1st ed. Munich: Institut für international Architektur.

Farzaneh, A., Monfet, D. and Forgues, D. (2019) 'Review of using Building Information Modeling for building energy modeling during the design process', Journal of Building Engineering. Elsevier Ltd, 23(August 2018), pp. 127-135. doi: 10.1016/j.jobe.2019.01.029.

Feist, W. et al. (2013) Passive House Planning Package. Passive House Institute.

Ghaffarianhoseini, A. et al. (2017) 'Building Information Modelling (BIM) uptake: Clear benefits, understanding its implementation, risks and challenges', Renewable and Sustainable Energy Reviews, 75(October 2015), pp. 1046-1053. doi: 10.1016/j.rser.2016.11.083.

Harris, F. and McCaffer, R. (2013) Modern Construction. doi: $10.1515 / 9783990434550$.

Junnila, S. and Horvath, A. (2003) 'Life-Cycle Environmental Effects of an Office Building', Journal of Infrastructure Systems, 9(4), pp. 157-166. doi: 10.1061/(ASCE)1076-0342(2003)9:4(157).

Kamel, E. and Memari, A. M. (2019) 'Review of BIM's application in energy simulation: Tools, issues, and solutions', Automation in Construction. Elsevier, 97(November 2018), pp. 164-180. doi: 10.1016/j.autcon.2018.11.008.

Krygiel, E. and Vandezande, J. (2014) Mastering Autodesk Revit Architecture 2015: Autodesk Official Press. Autodesk Official Press.

Miettinen, R. and Paavola, S. (2014) 'Beyond the BIM utopia: Approaches to the development and implementation of building information modeling',
Automation in Construction. Elsevier B.V., 43, pp. 84-91. doi: 10.1016/j.autcon.2014.03.009.

Motawa, I. and Carter, K. (2013) 'Sustainable BIM-based Evaluation of Buildings', Procedia - Social and Behavioral Sciences. Elsevier B.V., 74, pp. 419-428. doi: 10.1016/j.sbspro.2013.03.015.

Passipedia (2018) Passipedia - The Passive House Resource, Internationa Passive House Association. Available at: https://passipedia.org/ (Accessed: 26 November 2018).

Passivhaus Trust (2018). Available at: http://passivhaustrust.org.uk/ (Accessed: 26 November 2018).

Proietti, S. et al. (2013) 'Life Cycle Assessment of a passive house in a seismic temperate zone', Energy \& Buildings. Elsevier B.V., 64, pp. 463-472. doi: 10.1016/j.enbuild.2013.05.013.

Reinhardt, J. and Matthews, M. (2017) 'The Automation of BIM for Compliance Checking: a Visual Programming Approach', CITA BIM Gathering.

Seghier, T. E. et al. (2017) 'Building Envelope Thermal Performance Assessment Using Visual Programming and BIM, based on ETTV requirement of Green Mark and GreenRE', International Journal of Built Environment and Sustainability, 4(3), pp. 227-235. doi: 10.11113/ijbes.v4.n3.216.

The Passive House Institute (2018) Take a Tour. Available at: https://designph.org/product (Accessed: 17 December 2018).

Vierra, S. (2016) Green Building Standards and Certification Systems. Available at: https://www.wbdg.org/resources/green-buildingstandards-and-certification-systems (Accessed: 16 December 2018). 